\title{
Assessment of Metal Contamination in Ubeyi River and Accumulation in Fish and Sediment
}

\author{
*OGBONNA, PC; UKPAI, N; OBASI, KO
}

\author{
Department of Environmental Management and Toxicology, Michael Okpara University of Agriculture Umudike, P.M.B. 7267 Umuahia, \\ Abia State, Nigeria \\ *Corresponding author Email: ogbonna_princewill@yahoo.com,Tel: +2348063402809
}

\begin{abstract}
This study assessed heavy metals concentration and physicochemical characteristics in water, fish, and sediment at Ubeyi River in Ebonyi State, Nigeria using standard methods. Data obtained revealed that, the highest $\mathrm{pH}$ (6.225) and turbidity (60.35 NTU) were observed at the upstream. The highest BOD $(0.405 \mathrm{mg} / \mathrm{l})$ and EC (200.05 $\mu \mathrm{mhos} / \mathrm{cm})$ were obtained at the middle stream which were significantly $(\mathrm{P}<0.05)$ higher than values obtained at the upstream $(0.205 \mathrm{mg} / \mathrm{l}$ and $100.05 \mu \mathrm{mhos} / \mathrm{cm})$ and downstream $(0.067 \mathrm{mg} / \mathrm{l}$ and $40.05 \mu \mathrm{mhos} / \mathrm{cm})$. The highest value of TSS (101.50 mg/l) was observed at the downstream. Cd $(0.00015 \mathrm{mg} / \mathrm{l}), \mathrm{Cr}(4.125 \mathrm{mg} / \mathrm{l}), \mathrm{Zn}(2.615 \mathrm{mg} / \mathrm{l}), \mathrm{Ni}(1.47 \mathrm{mg} / \mathrm{l})$, and $\mathrm{Pb}(0.00015 \mathrm{mg} / \mathrm{l})$ in water at the upstream was statistically $(\mathrm{P}>0.05)$ the same with their corresponding values at middle stream $(0.00015,4.13,2.675,1.465$, and $0.00015 \mathrm{mg} / \mathrm{l})$ and downstream $(0.00015,4.135,2.305,1.445$, and $0.00015 \mathrm{mg} / \mathrm{l})$. Similarly, no statistical difference $(\mathrm{P}>0.05)$ exist in the values of metals in fish and sediment at the upstream, middle stream, and downstream. Dissolved oxygen and Turbidity of the river were higher than the permissible limit of $5.0 \mathrm{mg} / \mathrm{l}$ and $5.0 \mathrm{NTU}$ by WHO Codex Alimentarius while $\mathrm{Ni}, \mathrm{Pb}, \mathrm{Cr}, \mathrm{Cd}$ and $\mathrm{Zn}$ in water were below WHO permissible limit of $0.02,0.01,0.05,0.003$, and $1.0 \mathrm{mg} / \mathrm{l}$ in water, respectively.
\end{abstract}

\section{DOI: https://dx.doi.org/10.4314/jasem.v22i8.2}

Copyright: Copyright $\odot 2018$ Ogbonna and Idumah. This is an open access article distributed under the Creative Commons Attribution License (CCL), which permits unrestricted use, distribution, and reproduction in any medium, provided the original work is properly cited.

Dates: Received: 24 May 2018; Revised: 10 June: 2018; Accepted: 14 July 2018

Keywords: Metal, fish, sediment, Ubeyi, river

About $73 \%$ of the earth is covered by water bodies, but only $3 \%$ is fresh water suitable or fit for man's use (Dara, 1993). Thus, the contamination of water bodies is a serious challenge the world over due to increasing human activities that release pollutants such as heavy metals in the terrestrial and aquatic ecosystem (Ogbonna et al., 2013; Karbassi and Bayati, 2005). The increasing load of metals in aquatic ecosystems can disrupt the activities and lives of aquatic organisms since elevated concentrations of pollutants in the aquatic bodies may lead to bioaccumulation of metals in their various organs. The accumulation of metals in fish is one major route of entry of heavy metals in man's body since man depends on fish for protein, fish oil, vitamins and minerals.

Historically, Ubeyi River in Ndichima, Amoso Edda in Ebonyi State of Nigeria is the third largest River in Edda and flow across the communities. The river has for years, served as the only source of drinking water for the villagers, coolants for farmers, swimming for residents and laundry site for the villagers. Fish is one of the cheapest sources of protein, vitamins and minerals as well as income to the people of Amoso Edda. Notwithstanding this, man's unguided developmental projects around Edda and farmers' application of fertilizers to farmlands in the upland sides of the river, and the discharge of untreated effluents by industries may have resulted to contamination of Ubeyi River. Fish is an important indicator in water ecosystems for the estimation of metal pollution level (Rashed, 2001; Oguzie and Izevbigie, 2009). The concentration of heavy metals in aquatic ecosystems are also monitored by measuring their concentrations in sediments, water and phytoplankton (WHO 2000; Ani et al., 2016). This study therefore, is aimed to investigate the metal contamination in water, fish and sediment samples collected from Ubeyi River.

\section{MATERIALS AND METHODS}

Study area: Edda commonly referred to as Afikpo south is located at the Southern part of Ebonyi State which covers an area of about $144 \mathrm{Km}^{2}$ with a population of over 400,000 (Chudi, 2008). It is located between Latitude $5^{\circ} 45^{\prime}$ and $6^{\circ} 5^{\prime} \mathrm{N}$ and Longitude $7^{\circ}$ $55^{\prime}$ and $8^{\circ} 5^{\prime} \mathrm{E}$. The hottest months are February and March, with mean annual temperatures of $27^{\circ} \mathrm{C}$ in the undulating plains while the plateau area is $25^{\circ} \mathrm{C}$ (Suberu, 1994). The soils are acidic in nature and it 
composed mainly of sand, laterite, alluvial and sand stones.

Water samples collection and analysis: Prior to collection of water samples in August 2017, the bottle containers were washed and sterilized using autoclave at $121^{\circ} \mathrm{C}$ for 15 minutes. Thereafter, the bottle containers were neatly packed in well cleaned wooden box. Water samples were collected at three distinct sample stations in the River (the upstream where drinking water are fetched and no other activity takes place, the middle stream where people swim for pleasure, and the downstream of the river where laundry activities are carried out by the Villagers. Six representative water samples were collected at each sampling points (e.g. upstream) across the river at a distance of $5 \mathrm{~m}$ apart from each point of water sample collection and at the depth of less than one meter $(<1 \mathrm{~m})$. The six representative water samples from each sampling station were labeled well (e.g. upstream $1,2,3,4,5$ and 6) and placed in wooden box and taken to the laboratory for pre-treatment and analysis.

The six representative water samples from each sampling station (e.g. middle stream 1, 2,3,4,5 and 6) were mixed separately to form a homogenous sample. Then sub-samples from each of the homogenous water samples were acidified separately to $\mathrm{pH}$ of $<2$ with analytical grade nitric acid. A $250 \mathrm{ml}$ from each of the acidified water measured and transferred into separate clean conical flask and $5 \mathrm{ml}$ of nitric acid were added to each of the conical flasks. The mixtures were heated at $100^{\circ} \mathrm{C}$ with the addition of few drops of hydrogen peroxide until there was no brown visible fume coming out, and till the volume reduced to about 5 $\mathrm{cm}^{3}$. The mixture were then filtered separately using Whatman $0.45 \mu \mathrm{m}$ filter paper in a $25 \mathrm{ml}$ volumetric flask and topped to labeled mark. The samples of water were digested in triplicates and then transferred into separate plastic bottles which were labeled and placed on the wooden box for analysis. For the background correction, six blanks were digested as pre-test samples and each analyzed for $\mathrm{Pb}, \mathrm{Ni}, \mathrm{Mn}, \mathrm{Zn}, \mathrm{Cd}$ and $\mathrm{Cr}$ by atomic absorption spectrophotometer after calibration.

Determination of water temperature: This was determined on site at the time of sampling. A standardized pocket thermometer HANNA HI 2131 was immersed in the water sample and the reading was recorded.

Measurement of water $\mathrm{pH}$ : The $\mathrm{pH}$ of the water was measured using a pH meter HANNA HI 83141 (with a degree of accuracy 0.01) equipped with a temperature probe. The $\mathrm{pH}$ meter was initially calibrated by placing the $\mathrm{pH}$ electrode into a buffer solution of known $\mathrm{pH}(\mathrm{pH} 4)$ and the asymmetric potential control of the instrument adjusted until the meter read the known $\mathrm{pH}$ value of the buffer solution. Triplicate $\mathrm{pH}$ values were then taken.

Measurement of water electrical conductivity (EC): A high powered microcomputer conductivity meter HANNA HI 9828 with a degree of accuracy of 0.01 was used to measure the conductivity of the water samples in the laboratory within five hours of collection. Triplicate values were taken in units of micro Siemens per centimeter.

Measurement of Water Turbidity: Turbidity of the water samples was measured with a microprocessor turbidity meter WAGTECH 7100 after the samples was brought to the laboratory on ice and analyzed within five hours of collection. The instrument was first calibrated by dipping the probe into standard solution with turbidity values of 0.01 and 10.00 Nephelometric Turbidity Unit (NTU). This was done three times and the mean value was taken.

Collection of fish samples and analysis for metals ( $F e$, $\mathrm{Pb}, \mathrm{Cd}, \mathrm{Ni}, \mathrm{Zn}$ and $\mathrm{Cr}$ ): Fish samples were harvested at the different sampling stations (upstream, middle stream, and downstream) of the river. Six (6) fish samples (Tilapia zilli) of similar size were caught at each of the different sampling stations, placed in separate polythene bags, labeled well, placed in iced cooled plastic containers at $-20^{\circ} \mathrm{C}$ in wooden box and transported to the laboratory for pre-treatment and analysis. Later, the gills were dried at $105{ }^{\circ} \mathrm{C}$ in a gravity oven to constant weight. The dried six fish samples from each sampling station (e.g. upstream) were mixed and homogenized by grinding with a pestle and mortar into a fine powder and placed in well cleaned plastic bottles and labeled well. Triplicate digestion was performed following the procedure described by Türkmen and Ciminli (2007). For background correction, six blanks was digested as pretest samples and each of the blanks analyzed for $\mathrm{Pb}$, $\mathrm{Ni}, \mathrm{Mn}, \mathrm{Zn}, \mathrm{Cd}$ and $\mathrm{Cr}$ by atomic absorption spectrophotometer after calibration.

Sediment sampling and analysis: Six representative samples of sediment was collected at each of the different sampling station (upstream, middle stream, and downstream) with a PVC pipe of $5 \mathrm{~cm}$ diameter which was pushed with pressure through the water to obtain sediment layer at a depth of approximately 15 $\mathrm{cm}$. The six samples from each sampling station (e.g. downstream) were bulked together to form a homogenous sample, labeled well, placed in a wooden box and taken to the laboratory for pre-treatment and 
analysis. Tiny stones were carefully removed from each of the bulk sediments and oven dried at $105^{\circ} \mathrm{C}$ until there was no further change in weight. Each of the dried bulked samples were crushed separately with a well cleaned pestle and mortar to homogenize it. The homogenized samples were sieved with a sieve of 2 $\mu \mathrm{m}$ and packed in clean bottles prior to digestion and measurement of heavy metals. Sub-samples were collected separately from each of the bulked samples and triplicate digestions were performed following the procedure described by Türkmen and Ciminli (2007). For background correction, six blanks was digested as pre-test samples and each of the blanks analyzed for $\mathrm{Pb}, \mathrm{Ni}, \mathrm{Mn}, \mathrm{Zn}, \mathrm{Cd}$ and $\mathrm{Cr}$ by atomic absorption spectrophotometer after calibration.

Determination and calculation of concentration of metals: Regression equations established from a plot of absorbance readings of standards against their concentration was used to determine the concentration of $\mathrm{Pb}, \mathrm{Ni}, \mathrm{Mn}, \mathrm{Zn}, \mathrm{Cd}$, and $\mathrm{Cr}$ in triplicates.

Experimental design and statistical analysis: A Single Factor Experiment in a randomized complete block design (RCBD) was used to carry out the experiment. The data generated from laboratory analysis were subjected to analysis of variance (ANOVA) using Statistical Package for Social Sciences (SPSS) version 16.0. Analysis of variance was performed using a Oneway ANOVA and Duncan Multiple Range Test (DMRT) was used to test if significance difference existed between mean concentrations in physical parameters and heavy metals in water, fish and sediment from the different sampling stations.

\section{RESULTS AND DISCUSSION}

The results of the physical parameters of Ubeyi River is summarized in Table 1. The results indicate that the highest values for biological oxygen demand, BOD $(0.405 \mathrm{mg} / \mathrm{l})$ and electrical conductivity, EC (200.050 $\mu \mathrm{S} / \mathrm{cm}$ ) were obtained from middle stream, and these values were significantly $(\mathrm{p}<0.05)$ higher than their corresponding values at upstream $(0.205 \mathrm{mg} / \mathrm{L}$ and $100.05 \mu \mathrm{S} / \mathrm{cm})$ and downstream $(0.0675 \mathrm{mg} / \mathrm{L}$ and $40.05 \mu \mathrm{S} / \mathrm{cm})$, respectively. Biochemical oxygen demand (BOD) is a measure of the quantity of oxygen used by micro-organisms (e.g., aerobic bacteria) in the oxidation of organic matter. The oxygen consumed in the decomposition process robs other aquatic organisms of the oxygen needed to live. The highest BOD recorded at middle stream may be due to decaying organic matters and effluents discharged into the river at these points. The result corroborate with the findings of Sabahi (2007) who attributed his result to the natural plants (organic matters) decaying process coupled with other contributors that increase the total nutrient in water bodies such as the effluent from animal farm. The values of BOD in this study range from $0.0675 \mathrm{mg} / \mathrm{L}$ at downstream to 0.0405 $\mathrm{mg} / \mathrm{L}$ at upstream, which is well below $56.60 \pm 0.21$ $158.40 \pm 5.76 \mathrm{mg} / \mathrm{L}$ in Benue River (Anhwange et al., 2012), 1.20-7.03 mg/L (Omaka et al., 2014) as well as permissible limit of 3.0 (WHO, 2011). Electric Conductivity is a measure of the dissolved ionic component in water and hence electrical characteristic. Electrical conductivity gives an indication of the amount of total dissolved substitution in water (Yilmaz and Koc, 2014). Runoff and other human activities (Raut et al., 2011) in the river is implicated for the variation in EC values at the three sampling locations since the research was conducted during wet season. The lowest conductivity value at downstream may be due to the utilization of these substances by phytoplankton and other aquatic organism (Anhwange et al., 2012). High conductivity values have been reported to be indicative of pollution load of a river (Deeker et al., 2010) as well as tropic levels of aquatic body. The values of electrical conductivity (EC) in this study range from 40.05 to $200.05 \mu \mathrm{S} / \mathrm{cm}$ which is lower than $406 \pm 0.02 \mu \mathrm{S} / \mathrm{cm}$ observed in Isiagu River (Ukiwe et al., 2012).

Turbidity is the cloudiness of water caused by a variety of particles which may come from soil runoff. The lowest turbidity values of $40.05 \mathrm{NTU}$ and highest value of $60.35 \mathrm{NTU}$ were observed in samples from middle stream and upstream. The standard recommended maximum turbidity limit, set by WHO for drinking water is 5 NTU (WHO, 2011). The turbidity level recorded for Ubeyi River may be attributed to colour base organic matters due to clay profile of the study area carried to the river by surface run off during the wet season. The high turbidity may reduce light penetration into Ubeyi River, hence, affect photosynthetic processes. The adverse effect of turbidity on freshwater include decrease penetration of light rays (Deeker et al., 2010). The turbidity of Ubeyi river range from $40.050 \pm 13.08$ to $60.35 \mathrm{NTU}$ which is lower than $3.53 \pm 3.11$ to $97.67 \pm 5.21$ NTU in Azuiyikwu River (Omaka et al., 2014) but well above the maximum permissible limit of 5.0 NTU (WHO, 2011). The highest value of $\mathrm{pH}$ is recorded at the upstream $(6.225 \pm 0.00)$ and the value is significantly $(\mathrm{P}<0.05)$ higher than 5.945 \pm 0.00 and $5.925 \pm 0.00$ recorded at middle stream and downstream, respectively. Measurement of $\mathrm{pH}$ relates to the acidity or alkalinity of the water and a sample is considered to be acidic if the $\mathrm{pH}$ is below 7.0 while it is alkaline if the $\mathrm{pH}$ is higher than 7.0. According to WHO (2011), the normal drinking water $\mathrm{pH}$ ranges between 6.5 and 8.5 but the $\mathrm{pH}$ values of Ubeyi river samples range between 5.925 and 6.225 indicating slight acidity. The 
low $\mathrm{pH}$ of Ubeyi River may be attributed to dilution effect of rainfall since the research was carried out during wet season. The result agrees with Atobatele (2008) that $\mathrm{pH}$ decreases with increase rainfall. The decrease in $\mathrm{pH}$ during the wet season can be attributed to increase in organic matter brought about by rains which result in decrease in dissolved oxygen through the utilization of organic dehydration (Anhwange et al., 2012). Aquatic organisms are affected by change in $\mathrm{pH}$ because most of their metabolic activities are $\mathrm{pH}$ dependent. The highest value of dissolved oxygen, DO is obtained at downstream $(6.35 \pm 0.01 \mathrm{mg} / \mathrm{L})$ and the value is statistically equal $(\mathrm{P}>0.05)$ with upstream $(6.05 \pm 0.00 \mathrm{mg} / \mathrm{L})$ but significantly $(\mathrm{P}<0.05)$ higher than $5.85 \pm 0.00 \mathrm{mg} / \mathrm{L}$ obtained at the middle stream.

The lower value of DO observed at middle stream may be due to phytoplankton bloom and decomposition of organic materials. The DO of Ubeyi River is relatively higher than $5.0 \mathrm{mg} / \mathrm{L}$ recommended by WHO (2011). Rivers with low BOD have low nutrient levels and this implies high concentration of dissolved oxygen (Anhwange et al., 2012). Consequently, the low BOD of Ubeyi River resulted to higher DO of the river (Table 1). The highest content of total suspended solid, TSS is obtained at the downstream $(101.50 \mathrm{mg} / \mathrm{L})$ which is significantly $(\mathrm{P}<0.05)$ higher than the values obtained at middle stream $(91.50 \mathrm{mg} / \mathrm{L})$ and upstream (77.50 mg/L).

The highest value of $101.5 \mathrm{mg} / \mathrm{L}$ recorded in river samples from downstream falls within the maximum standard limit of $80-150 \mathrm{mg} / \mathrm{L}$ (WHO, 2011). The values of temperature in Ubeyi River did not differ significantly $(\mathrm{P}>0.05)$ at upstream $\left(27.05 \pm 0.00{ }^{\circ} \mathrm{C}\right)$, middle stream $\left(\left(27.05 \pm 0.00{ }^{\circ} \mathrm{C}\right)\right.$ and downstream $\left(27.05 \pm 0.00{ }^{\circ} \mathrm{C}\right)$, respectively. The high turbidity of Ubeyi River may have reduced penetration of light rays into the water body. This, in turn, resulted to equal temperatures at upstream, middle stream and downstream of the river. The temperature of Ubeyi River is relatively higher than $23.0^{\circ} \mathrm{C}$ recommended by WHO (2011). High temperature impact negatively on water quality by enhancing the growth of microorganisms which may increase colour (UNICEF, 2008). Therefore, it is important that temperature of Ubeyi River is not too high in order not to have microbial proliferation and decreases solubility of gases such as $\mathrm{O}_{2}, \mathrm{CO}_{2}$ (Yilmaz and Koc, 2014; Oyem et al., 2014). The temperature of any given water determines the rate of metabolism of aquatic organism and the concentration of dissolved gases (Anhwange et al., 2012).

The concentration of metals in water samples from Ubeyi River is presented in Table 2. The result show that the concentrations of $\mathrm{Cd}(0.00015 \pm 0.00$, $0.00015 \pm 0.00$ and $0.00015 \pm 0.00 \mathrm{mg} / \mathrm{L}), \quad \mathrm{Cr}$ $(0.000011 \pm 0.00,0.000012 \pm 0.00$ and $0.000017 \pm 0.00$ $\mathrm{mg} / \mathrm{L}), \quad \mathrm{Zn} \quad(0.000016 \pm 0.00, \quad 0.000016 \pm 0.00$ and $0.000022 \mathrm{mg} / \mathrm{L}), \mathrm{Ni}(0.000014 \pm 0.00,0.000017 \pm 0.00$ and $0.000013 \mathrm{mg} / \mathrm{L})$, and $\mathrm{Pb} \quad(0.00015 \pm 0.00$, $0.00015 \pm 0.00$ are statistically equal at upstream, middle stream and downstream, respectively (Table 2). According to Murdock et al. (2001), decrease in $\mathrm{pH}$ of water increases the solubilization of some metals, especially when the $\mathrm{pH}$ falls below 4.5.

The $\mathrm{pH}$ of Ubeyi River is high and it is implicated for the equal concentration off metals at upstream, middle stream and downstream. The highest concentrations of $\mathrm{Ni}(0.000017 \mathrm{mg} / \mathrm{l}), \mathrm{Pb}(0.000014 \mathrm{mg} / \mathrm{l}), \mathrm{Cr}(0.000017$ $\mathrm{mg} / \mathrm{l}), \mathrm{Cd}(0.000015 \mathrm{mg} / \mathrm{l})$, and $\mathrm{Zn}(0.000022 \mathrm{mg} / \mathrm{l})$ in water samples from Ubeyi River is well below the permissible limit of $0.02 \mathrm{mg} / 1,0.01 \mathrm{mg} / 1,0.05 \mathrm{mg} / \mathrm{l}$, $0.003 \mathrm{mg} / \mathrm{l}$, and $1.0 \mathrm{mg} / \mathrm{l}$ for $\mathrm{Ni}, \mathrm{Pb}, \mathrm{Cr}, \mathrm{Cd}$ and $\mathrm{Zn}$ in water (WHO 2000).

Table 1: Some physical parameters of Ubeyi River

\begin{tabular}{llllllll}
\hline $\begin{array}{l}\text { Sampling } \\
\text { station }\end{array}$ & $\begin{array}{l}\text { BOD } \\
\mathbf{m g} / \mathbf{L}\end{array}$ & $\mathbf{E C} \mu \mathrm{SS} / \mathrm{cm}$ & $\begin{array}{l}\text { DO } \\
\mathbf{m g} / \mathbf{L}\end{array}$ & $\begin{array}{l}\text { TSS } \\
\mathbf{m g} / \mathbf{L}\end{array}$ & $\begin{array}{l}\text { Temp. } \\
{ }^{\mathbf{0}} \mathbf{C}\end{array}$ & $\begin{array}{l}\text { Turbidity } \\
\text { NTU }\end{array}$ & $\mathbf{p H}$ \\
\hline Upstream & $0.2050^{\mathrm{b}} \pm 0.00$ & $100.050^{\mathrm{b}} \pm 0.02$ & $6.050^{\mathrm{a}} \pm 0.00$ & $77.50^{\mathrm{c}} 0.01$ & $27.050^{\mathrm{a}} \pm 0.01$ & $60.350^{\mathrm{a}} \pm 0.01$ & $6.2250^{\mathrm{a}} \pm 0.00$ \\
Middlestream & $0.4050^{\mathrm{a}} \pm 0.01$ & $200.050^{\mathrm{a}} \pm 0.01$ & $5.850^{\mathrm{b}} \pm 0.00$ & $91.50^{\mathrm{b}} \pm 0.01$ & $27.050^{\mathrm{a}} \pm 0.01$ & $40.050^{\mathrm{c}} \pm 0.01$ & $5.9450^{\mathrm{b}} \pm 0.00$ \\
Downstream & $0.067 \mathrm{c} \pm 0.01$ & $40.050^{\mathrm{c}} \pm 0.00$ & $6.350^{\mathrm{a}} \pm 0.01$ & $101.50^{\mathrm{a}} 0.01$ & $27.050^{\mathrm{a}} 0.01$ & $52.550^{\mathrm{b}} \pm 0.01$ & $5.9250^{\mathrm{b}} \pm 0.00$ \\
wHO & 3.00 & 400 & 5.0 & $<80-150$ & 23.50 & 5 & $6.5-8.5$ \\
\hline \multicolumn{6}{c}{ \pm Standard deviation $(S D)^{\text {abc }}$ means across column with different superscript differ significantly at $P<0.05$}
\end{tabular}

Table 2: Metal concentration (mg/L) in water samples collected from Ubeyi River

\begin{tabular}{|c|c|c|c|c|c|c|}
\hline $\begin{array}{l}\text { Sampling } \\
\text { position }\end{array}$ & $\mathrm{Cd}$ & $\mathrm{Cr}$ & $\mathbf{Z n}$ & $\mathrm{Ni}$ & $\mathrm{Pb}$ & Mn \\
\hline Upstream & $0.000150 \pm 0.00^{2}$ & $0.000011 \pm 0.00^{2}$ & $0.000016 \pm 0.00^{2}$ & $0.000014 \pm 0.00^{2}$ & $0.000150 \pm 0.00^{2}$ & 0.00125 \\
\hline Middles tream & $0.000150 \pm 0.00^{=}$ & $0.000012=0.00^{2}$ & $0.000016 \pm 0.00^{=}$ & $0.000017 \pm 0.00^{\mathrm{a}}$ & $0.000150 \pm 0.00^{=}$ & 0.00115 \\
\hline Downstream & $0.000150 \pm 0.00^{\mathrm{a}}$ & $0.000017 \pm 0.00^{=}$ & $0.000022 \pm 0.00^{\mathrm{s}}$ & $0.000013 \pm 0.00^{\mathrm{a}}$ & $0.000150 \pm 0.00^{\mathrm{a}}$ & 0.00200 \\
\hline WHO & $<0.10$ & $<0.05$ & 5.00 & $<0.10$ & 0.05 & 0.20 \\
\hline
\end{tabular}

\pm Standard deviation $(S D)^{a b c}$ means across column with different superscript differ significantly at $P<0.05$ 
The highest concentration of $\mathrm{Mn}$ is obtained at the downstream $(0.0020 \mathrm{mg} / \mathrm{L})$ which is significantly $(\mathrm{P}<0.05)$ higher than values obtained from upstream $(0.00125 \mathrm{mg} / \mathrm{L})$ and middle stream $(0.00115 \mathrm{mg} / \mathrm{L})$. The highest concentration of Mn at downstream may be attributed to laundry activities carried out by local inhabitants which released Mn in some tablets of soap used during washing. The highest value of Mn (0.002 $\mathrm{mg} / \mathrm{L}$ ) in this study is lower than the maximum acceptable limit of $0.05 \mathrm{mg} / \mathrm{L}$ of $\mathrm{Mn}$ in water (WHO, 2008). The contamination of Ubeyi River may be attributed to discharge of untreated effluents from industry cited close to the course of the river vis-à-vis run off from upland farms that farmers use fertilizer to boost crop yield.

The result of heavy metal concentration in fish sampled from Ubeyi River is summarized in Table 3. The result indicate that the concentrations of $\mathrm{Pb}$ $(0.00015 \pm 0.00, \quad 0.00015 \pm 0.00$ and $000.15 \pm 0.00$ $\mathrm{mg} / \mathrm{kg}), \mathrm{Ni}(1.59 \pm 0.01,1.55 \pm 0.08$ and $1.56 \pm 0.00$ $\mathrm{mg} / \mathrm{kg}), \mathrm{Cr}(2.92 \pm 0.01,2.95 \pm 0.04$ and $2.90 \pm 0.01$ $\mathrm{mg} / \mathrm{kg})$, and $\mathrm{Cd}(0.00015 \pm 0.00,0.00015 \pm 0.00$ and $0.00015 \pm 0.00 \mathrm{mg} / \mathrm{kg}$ ) in fish at upstream, middle stream and downstream are statistically $(\mathrm{P}>0.05)$ equal and this may be attributed to even distribution of these metals $(\mathrm{Pb}, \mathrm{Ni}, \mathrm{Cr}$ and $\mathrm{Cd})$ in the water body and possible accumulation in fish via the gills. However, ingestion of prey (food) contaminated with metals may also have contributed to metal loads in fish. The concentrations of $\mathrm{Pb}(0.00015 \pm 0.00 \mathrm{mg} / \mathrm{kg})$ and $\mathrm{Cd}$ $(0.00015 \pm 0.00 \mathrm{mg} / \mathrm{kg})$ in fish is below the maximum permissible limit 0.05 and $<0.01$. Notwithstanding this, low-level chronic exposure to $\mathrm{Pb}$ cause adverse health effects such as neurological and reproductive effects. For instance, consumption of food stuff contaminated with $\mathrm{Pb}$ and $\mathrm{Cd}$ in Copsa Mica and Bala Mare, Romania significantly contribute to decrease human life expectancy by 9 to 10 years (Lacatusu et al., 1996). The source of metals in Ubeyi River may be attributed to a small industry located near the course of the river, despite the possible source of contamination from erosion of natural deposits. The concentrations of $\mathrm{Ni}(1.59 \pm 0.01 \mathrm{mg} / \mathrm{kg})$ and $\mathrm{Cr}$ $(2.95 \pm 0.04 \mathrm{mg} / \mathrm{kg})$ in fish is higher than maximum permissible limit $<0.10$ and $<0.05$ (WHO, 2008), respectively. The high concentrations of $\mathrm{Ni}$ is dangerous to the health and survival of people of Amosso Edda that depend on fish as their source of livelihood. Chromium causes serious developmental effects (ATSDR 1999) while excess intake of Ni leads to reproductive failures and growth problems (Kumar et al., 2007). The result also show that highest and lowest concentrations of $\mathrm{Mn}$ and $\mathrm{Zn}$ were observed at middle stream $(2.15 \pm 0.07 \mathrm{mg} / \mathrm{kg})$ and upstream $(12.18 \pm 0.00 \mathrm{mg} / \mathrm{kg})$, respectively. The concentrations of $\mathrm{Mn}$ increased from $1.99 \pm 0.01 \mathrm{mg} / \mathrm{kg}$ at upstream to $2.15 \pm 0.07 \mathrm{mg} / \mathrm{kg}$ at middle stream while $\mathrm{Zn}$ increased from $12.00 \pm 0.02 \mathrm{mg} / \mathrm{kg}$ at downstream to $12.18 \pm 0.00$ $\mathrm{mg} / \mathrm{kg}$ at upstream. The range of $\mathrm{Mn}(1.99 \pm 0.01-$ $2.15 \pm 0.07 \mathrm{mg} / \mathrm{kg})$ and $\mathrm{Zn}(12.00 \pm 0.02-12.18 \pm 0.00$ $\mathrm{mg} / \mathrm{kg}$ ) in fish is well above the maximum permissible limit of 0.02 and 5.0 (WHO, 2011), respectively. $\mathrm{Zn}$ is an essential element required to maintain proper functions of the immune system but its concentration beyond permissible limit can result to serious health risks.

The results of the sediment samples collected from Ubeyi River is presented in Table 4. The result indicates that the concentration of $\mathrm{Pb}(0.00015 \pm 0.00$, $0.00015 \pm 0.00$ and $0.00015 \pm 0.00 \mathrm{mg} / \mathrm{L}), \mathrm{Ni}$ $(1.470 \pm 0.00,1.465 \pm 0.00$, and $1.445 \pm 0.00 \mathrm{mg} / \mathrm{L}), \mathrm{Zn}$ $(2.62 \pm 0.00,2.68 \pm 0.04$, and $2.31 \pm 0.44 \mathrm{mg} / \mathrm{L}), \mathrm{Cr}$ $(4.13 \pm 0.00,4.13 \pm 0.01$ and $4.14 \pm 0.02 \mathrm{mg} / \mathrm{L})$ and $\mathrm{Cd}$ $(0.00015 \pm 0.00, \quad 0.00015 \pm 0.00$ and $0.00015 \pm 0.00$ $\mathrm{mg} / \mathrm{L}$ ) is the same at upstream, middle stream and downstream, respectively. This suggest that $\mathrm{Pb}, \mathrm{Ni}$, $\mathrm{Zn}, \mathrm{Cr}$ and $\mathrm{Cd}$ were evenly distributed at the floor of the river. The values of $\mathrm{Ni}$ ranged from $1.445 \pm 0.00$ at downstream to $1.470 \pm 0.00 \mathrm{mg} / \mathrm{L}$ at upstream which is higher than $0.31 \mathrm{mg} / \mathrm{L}$ of Ndibe River in Ebonyi State (Nwani et al., 2010). The values of Mn ranged from $15.92 \pm 0.03-16.84 \pm 0.03 \mathrm{mg} / \mathrm{L}$, which is well above the maximum acceptable limit of 0.05 (WHO, 2008).

\begin{tabular}{|c|c|c|c|c|c|c|}
\hline Sampling station & $\mathbf{P b}$ & $\mathbf{N i}$ & Mn & $\mathbf{Z n}$ & $\mathbf{C r}$ & Cd \\
\hline Upstream & $0.00015 \pm 0.00^{\mathrm{a}}$ & $1.59 \pm 0.01^{\mathrm{a}}$ & $1.99 \pm 0.01^{\mathrm{a}}$ & $12.18 \pm 0.00^{\mathrm{a}}$ & $2.92 \pm 0.01^{\mathrm{a}}$ & $0.00015 \pm 0.00^{\mathrm{a}}$ \\
\hline MiddleStream & $0.00015 \pm 0.00^{\mathrm{a}}$ & $1.55 \pm 0.08^{\mathrm{a}}$ & $2.15 \pm 0.07^{\mathrm{a}}$ & $12.17 \pm 0.03^{\mathrm{a}}$ & $2.95 \pm 0.04^{\mathrm{a}}$ & $0.00015 \pm 0.00^{\mathrm{a}}$ \\
\hline DownStream & $0.00015 \pm 0.00^{\mathrm{a}}$ & $1.56 \pm 0.04^{\mathrm{a}}$ & $2.05 \pm 0.07^{\mathrm{b}}$ & $12.00 \pm 0.02^{\mathrm{b}}$ & $2.90 \pm 0.01^{\mathrm{a}}$ & $0.00015 \pm 0.00^{\mathrm{a}}$ \\
\hline WHO & 0.05 & $<0.10$ & 0.02 & 5.00 & $<0.05$ & $<0.01$ \\
\hline
\end{tabular}

Table 4: Metal concentration $(\mathrm{mg} / \mathrm{L})$ in sediment in Ubeyi River

\begin{tabular}{lllllll}
\hline Sampleing station & $\mathbf{P b}$ & $\mathbf{N i}$ & $\mathbf{M n}$ & $\mathbf{Z n}$ & $\mathbf{C r}$ & $\mathbf{C d}$ \\
\hline Upstream & $0.00015 \pm 0.00^{\mathrm{a}}$ & $1.470 \pm 0.00^{\mathrm{a}}$ & $16.84 \pm 0.03^{\mathrm{a}}$ & $2.62 \pm 0.00^{\mathrm{a}}$ & $4.13 \pm 0.00^{\mathrm{a}}$ & $0.00015 \pm 0.00^{\mathrm{a}}$ \\
MiddleStream & $0.00015 \pm 0.00^{\mathrm{a}}$ & $1.465 \pm 0.00^{\mathrm{a}}$ & $15.92 \pm 0.03^{\mathrm{b}}$ & $2.68 \pm 0.04^{\mathrm{a}}$ & $4.13 \pm 0.01^{\mathrm{a}}$ & $0.00015 \pm 0.00^{\mathrm{a}}$ \\
DownStream & $0.00015 \pm 0.00^{\mathrm{a}}$ & $1.445 \pm 0.00^{\mathrm{a}}$ & $16.05 \pm 0.07^{\mathrm{b}}$ & $2.31 \pm 0.44^{\mathrm{a}}$ & $4.14 \pm 0.02^{\mathrm{a}}$ & $0.00015 \pm 0.00^{\mathrm{a}}$ \\
WHO & 0.05 & $<0.10$ & 0.02 & 5.00 & $<0.05$ & $<0.01$ \\
\hline \multicolumn{5}{c}{ \pm Standard deviation $(S D)^{a b c}$ means across column with different superscript differ significantly at $P<0.05$}
\end{tabular}


The high concentration of Mn observed in Ubeyi River is attributed to surface run off from the upland farms. The values of $\mathrm{Zn}$ in sediment is higher than $1.75 \pm 0.5$ $\mathrm{mg} / \mathrm{L}$ in sediment (Afiukwu and Eboatu, 2013). Cr concentration in sediment ranged from $4.13 \pm 0.00$ to $4.14 \pm 0.02 \mathrm{mg} / \mathrm{L}$ which is higher than the maximum permissible limit of (0.05) by WHO (2008). In this study, the concentration of metals in sediment and fish were relatively higher than their corresponding values in water. The higher concentration in fish may be attributed to bio-magnification of metals in smaller organisms such as earthworm, insects and phytoplanktons that serve as food for fish as well as ingestion of water via the gills while concentration of metals in sediment may be attributed to metal contaminated phytoplankton's that died and deposit in sediment. Metals are required for numerous processes in phytoplankton. Metal composition in phytoplankton reflect biochemical demand and environmental availability. This, in turn, influences the distribution of metals in water bodies (Karin and Terry, 2004) especially in sediment.

Conclusion: According to World Health Organization standard, the concentration of some metals exceeded their maximum acceptable limit in water and fish. The physical parameters (dissolved oxygen, temperature, and turbidity) also exceeded their maximum permissible limit in water. Therefore, it is concluded that the utilisation of water and consumption of fish in Ubeyi River will constitute serious health risks to human life.

\section{REFERENCES}

Afiukwa, JN; Eboatu, AN (2013). Analysis of spring water quality in Ebonyi South Zone and its health impact. Am. J. Sci. Ind. Res. 4(2): 2153-2649.

Agency for Toxic Substances and Disease Registry, ATSDR (1999). Toxicological Profile for Lead. Agency for Toxic Substances and Disease Registry, US Department of Health and Human Services, Public Health Service.

Anhwange, BA; Agbaji, EB; Gimba, EC (2012). Impact assessment of human activities and seasonal variation on River Benue, within Makurdi metropolis. Int. J. Sci. Technol. 2(5): 248-254.

Ani, CI; Okogwu, OI; Nwonumara, GN; Nwani, CD; Nwinyimagu, AJ (2016). Evaluation of physicochemical parameters of selected rivers in Ebonyi State, Southeast, Nigeria. Greener J. Biol. Sci. 6(2): 034-041.
Atobatele, OE; Ugwumbe, OA (2008). Seasonal variation in the physicochemistry of a small tropical reservoir (Aiba Reservoir, Iwo, Osun, Nigeria). Afr. J. Biotechnol. 7(12): 1962-1972.

Chudi, A (2008). Edda topography, road construction problem Edda Afikpo South, Ebonyi State, Nigeria.

Dara, SS (1993). A textbook of Environmental Chemistry and pollution control. Chand and Company limited, Ram Nagar, New Delhi.

Deeker, S.N., Abowei, J.F.N. and Alfred-Ockiya, J.F. (2010). Seasonal Variation of Some Physical and Chemical Parameters of Luubara Creek, Ogoni Land, Nigeria. Res. J. Environ. Earth Sci. 2(4): 208-215.

Karbassi, A; Bayati, GR (2005). Environmental geochemistry of heavy metals in a sediment core of Bushehr, Persian Gulf. Iranian J. Environ. Health Sci. Engr. 2: 255 - 260.

Karin, K; Terry, B (2004). Sources of lead exposure and intellectual impairment in children. Environ. Health Persp. 112: 987 - 993.

Kumar NJI; Soni, H; Kumar, RN (2007). Characterization of Heavy Metals in Vegetables Using Inductive Coupled Plasma Analyzer (ICPA). J. Appl. Sci. Environ. Manage. 11(3): 7579.

Lacatusu, R; Rauta, C; Carstea, S; Ghelase, I (1996). Soil-plant-man relationships in heavy metal polluted areas in Romania. Appl. Geochem. 11: $105-107$.

Nwani, C. D., Nwachi, D. A., Okogwu, O. I., Ude, E. F. and Odoh, G. E. (2010). Heavy metals in fish species from lotic freshwater ecosystem at Afikpo, Nigeria. Journal of Environmental Biology, 31(5): 595-601.

Odoemelam, SA; Okorie, DO; Oko, IO (2013). Physicochemical parameters and heavy metal content of water, fish and sediments from Cross River at Afikpo north local Government area of Ebonyi State, Nigeria. Biores. Bull. 3: 10 - 15 .

Ogbonna, PC; Odukaesieme, C; Teixeira da Silva, JA (2013). Distribution of heavy metals in soil and accumulation in plants at an agricultural area of Umudike, Nigeria. Chem. Ecol. 29(7): 595-603. 
Oguzie, FA; Izevbigie, EE (2009). Heavy metals concentration in the organs of the silver Catfish, Chrysichthy snigrodigitatus (Lacèpéde) caught upstream of the Ikpoba river and the reservoir in Benin City. Biosci. Res. Commun. 21: 189- 197.

Omaka, ON; Nwabue, FI; Itumoh, EJ; Oroke, EC; Igwe, DO (2014). Physicochemical parameter and nutrients and rivers in Abakiliki, Ebonyi State, Nigeria. Global NEST J. 16(1): 114-123.

Oyem, HH; Oyem, IM; Ezeweali, D (2014). Temperature, $\mathrm{pH}$, electrical conductivity, total dissolved solids and chemical oxygen demand of groundwater in Boji-BojiAgbor/Owa area and immediate suburbs. Research Journal of Environmental Sciences, 8: 444-450.

Rashed, MN (2001). Monitoring of environmental heavy metals in fish from Nasser Lake. Environ. Int. 27:27-33.

Raut, KS; Shinde, SE; Pathan, TS; Sonawane, DC (2011). Seasonal variation in physico-chemical characteristics of Ravivar Lake at Ambajogai District, beed Maarathwada Region, India. J. Res. Biol. 4: 258 - 262 .

Sabahi, EM (2007). A study of surface water and ground water pollution in Ibb city, Yemen $(\mathrm{PhD}$ Dissertation), University of Kebangsaan Malaysia, Selangor, Malaysia.

Suberu, RT (1994). State and Local Government reorganizations in Nigeria. Institute of African Studies, University of Ibadan, Ibadan, Nigeria.
Türkmen, M; Ciminli, C (2007). Determination of metals in fish and mussel species by Inductively Coupled Plasma-atomic emission spectrometry. Food Chem. 103: 670 - 675.

Ukiwe, LN; Onyedika, GO; Uche, VI; Iwu, CI (2012). Physicochemical water quality indicators of groundwater in Ishiagu, Ebonyi State, Nigeria. Terr. Aquat. Environ. Toxicol. 6(1): 55-60.

UNICEF (2008). United Nations Children's Education Fund handbook on water quality, New York, USA.

World Health Organization, WHO (2000). Hazardous chemical in Human and Environmental Health, Geneva.

World Health Organization, WHO (2002). Managing water in the home: Accelerated health gains from improved water supply, Geneva.

World Health Organization, WHO (2008) Guidelines for drinking water quality, World health organization, Geneva.

World Health Organization, WHO (2011). Guidelines for Drinking-Water Quality, WHO Press, Geneva, Switzerland, 4th edition.

Yilmaz, E; Koc, C (2014). Physically and chemically evaluation for the water quality criteria in a farm on Akcay. J. Water Resour. Prot. 6: 63 - 67. 